\title{
Золото-ильменитовые россыпи интрузий ультрабазитов Сихотә-Алиня: минералогия, геохимия и происхождение
}

\author{
Молчанов В.П. ${ }^{1}$, Молчанова Н.Н. ${ }^{2}$ \\ ${ }^{1}$ Дальневосточный геологический институт ДВО РАН, Владивосток, vpmol@mail.ru \\ 20ОО «Гидрометаллург», Владивосток,631135@таil.ru
}

Аннотация. Определены основные черты минералогии и геохимии, а также рудный потенциал титаноносных россыпей, пространственно и генетически связанных с Ариадненской интрузией ультрабазитов (Приморье). Изучен состав ильменита, золота и платины, выявлен комплекс попутных стратегических металлов. Полученные данные позволили сделать вывод об участии в россыпеобразовании полигенных и полихронных коренных источников. В качестве поставщика ильменита, платины, медистого и ртутистого золота выступали базит-ультрабазиты. Другим источником питания россыпей, повидимому, послужили кварцево-жильные образования с золото-сурьмянной минерализацией. Углубленные минералого-геохимические исследования ильменитовых россыпей базит-ультрабазитов Сихотэ-Алиня позволят расширить перспективы сырьевой базыюга Дальнего Востока.

Ключевые слова: ильменит, платина, серебристое, медистое и ртутистое золото, титаносные россыпи, ультрабазиты, Ариадненский массив, Приморье.

\section{Gold-ilmenite placers of intrusions of ultrabasites of Sikhote-Alin: mineralogy, geochemistry and origin}

\author{
Molchanov V.P. ${ }^{1}$, Molchanova N.N. ${ }^{2}$ \\ ${ }^{1}$ Far East Geological Institute, Far Eastern Branch of the RAS, Vladivostok, vpmol@mail.ru \\ ${ }^{2}$ Limited Liability Company «Hydrometallurg»,Vladivostok, Russia,631135@mail.ru
}

\begin{abstract}
The main features of mineralogy and geochemistry, as well as the ore potential of titanium-bearing placers, spatially and genetically associated with the Ariadne intrusion of ultrabasites (Primorye), are determined. The composition of ilmenite, gold and platinum was studied, a complex of associated strategic metals was revealed. The data obtained allowed us to make a conclusion about the participation of polygenic and polychronous indigenous sources in placer formation. The mafic ultramafites were a supplier of ilmenite, platinum, copper and mercury gold. Another power source of the placers, apparently, was the quartz-vein formation with gold mineralization surmandal. The experience of extracting strategic mineral raw materials from a variety of minerals requires careful study in relation to the conditions of the Far Eastern region.

Key words: ilmenite, platinum, copper gold, mercury gold, titanium-bearing placer, ultrabasites, Ariadnensky massif, Primorsky Region.
\end{abstract}

\section{Введение}

Приморье относится к числу наиболее старых районов золотодобычи России (Анерт, 1928). Благородные металлы здесь добывали задолго до прихода первых русских поселенцев. Интенсивная эксплуатация россыпных месторождений золота на протяжении многих лет привела к истощению их геологических запасов, что не могло не отразиться на резком снижении объемов добычи благородных металлов (БМ). Вместе с тем, есть весомые основания полагать, что минеральносырьевой потенциал региона далеко не исчерпан. Нужны новые подходы к прогнозу, поискам и освоению источников стратегических минеральных ресурсов. Одними из таких альтернативных источников являются комплексные проявления экзогенной минерализации, в которых стратегические металлы являются попутными компонентами. Издавна к стратегическим металлам относят твердые виды полезных ископаемых, существенные для национальной безопасности. Так, золото обеспечивает финансовую безопасность государства. В последние годы другие металлы приобрели критическую важность для многих промышленных отраслей. Перейдя из категории экзотических металлов в стратегические ресурсы, они оказались крайне востребованными технологиями будущего: редко- 
земельные элементы для производства мобильных телефонов, компьютеров, а титан - для применения в медицине и авиастроении и т.д. В конце прошлого века в рубежной литературе появились понятия «критические металлы» и «критическое минеральное сырье», прочно утвердившееся настоящее в экономике ведущих промышленно-развитых стран. Они включают твердые полезные ископаемые, практически незаменимые для развития наукоемких технологий, но крайне рискованные в своем получении потребителем. Многие из этих критических металлов (титан, металлы платиновой группы, редкоземельные элементы, ниобий, тантал, гафний, ванадий, кобальт, сурьма) присутствуют в рудах и россыпях базитов и гипербазитов Приморья, указывая на необходимость проведение геолого-разведочных работ. Примером тому может послужить Ариадненская интрузия ультрабазитов и сопровождающий ее довольно широкий спектр рудо-россыпепроявлений полезных компонентов. Изучение типоморфных свойств основных и попутных россыпеобразующих минералов, в первую очередь ильменита, самородных золота и платины, позволит не только идентифицировать источники питания россыпей и локализовать участки их максимального распространения, но и оценить возможности извлечения этих полезных компонентов.

\section{Методы исследований}

Минералогические исследования осуществлялись с применением электронно-зондового микроанализатора JeolSuperprobe JXA 8100 с системой INCA Energy 350 OxfordInstruments и электронного сканирующего микроскопа EVO-500XVP с системой INCA Energy 350 OxfordInstruments.

Анализ микроэлементного состава проб был выполнен на масс-спектрометре с индуктивно связанной плазмой (ИСП-МС) Agilent 7500c (AgilentTechnologies, Япония), оборудованном распылителем Бабингтона, охлаждаемой распылительной камерой Скотта и заземленной горелкой Фассела. Использовались никелевые конусы самплера и скиммера. Определение петрогенных элементов проводилось на атомно-эмиссионном с индуктивно связанной плазмой спектрометре iCAP 6500 Duo (ИСП-АЭС) (ThermoScientific, США).

Технологические исследования были выполнены по традиционной для обогащения ильменитсодержащих песков схеме с предварительным гравитационным обогащением и последующей электромагнитной сепарацией. При этом использовались серийные концентрационные столы и электромагнитные сепараторы мокрого типа.

\section{объект исследований}

Ариадненский массив базит-ультрабазитов, расположенный в среднем течении р. Малиновка (площадь водосбора р. Уссури, притока р. Амур), относится к группе дифференцированных интрузий Ариадненского металлогенического пояса, приуроченных к Самаркинскому террейну юрской аккреционной призмы. В геологическом строении Ариадненского рудно-россыпного узла, совпадающего с контурами одноименного массива, принимают участие верхнеюрские турбидиты и олистостромы аккреционной призмы с включениями позднепалеозойских и нижнемезозойских океанических кремней, сланцев, известняков и базальтов, которые прорваны Ариадненской интрузией базит-ультрабазитов раннемелового возраста. Ее южная часть сложена перидотитами и оливиновыми пироксенитами, к северу преобладают ильменитовые и роговообманковые габбро, переходящие в диориты, монцодиориты и сиениты. Вышеперечисленные стратифицированные и магматические образования, в свою очередь, прорваны поздними гранитоидами, дайками основного и кислого состава позднемелового возраста (Геодинамика..., 2006).

С габброидами связано Ариадненское проявление ильменитовой минерализации. Рудные тела представляют собой залежи сложной морфологии северо-восточного простирания протяженностью до 2200 м при ширине до 400 м, и прослеженные по падению до 400 м. Среднее содержание $\mathrm{TiO}_{2}$ в них составляет $6.16 \%, \mathrm{~V}_{2} \mathrm{O}_{5}-0.086 \%, \mathrm{Fe}_{2} \mathrm{O}_{3}-13.28 \%, \mathrm{Sc}-0.0045 \%$. С глубиной в руде отмечается увеличение концентрации $\mathrm{Cu}$ и $\mathrm{Ni}$, достигающих, соответственно, 0.1 и 0.3 \%.В верховьях р. Падь Тодохова широко развита сеть северо-восточных разрывных нарушений, контролирующих положение кварцевых жил с золото-сурьмяной минерализацией Тодоховского рудопроявле- 
ния. Большей частью они приурочены к экзоконтакту ультрабазитов с песчаниками и алевролитами. По простиранию они, по данным В.М. Лосива (1990 г.) прослежены до 4000 м, по падению - до 400 м. Главный рудный минерал - антимонит, реже встречаются арсенопирит, пирит, марказит. Содержания основных полезных компонентов варьируют в следующих пределах: $\mathrm{Sb}$ - 0.18-23.4 мас. \%, (среднее - 2.2 мас. \%), Ag - 500-1820 г/т; $\mathrm{Au}-0.14-0.74$ г/т (среднее - 0.3 г/т).

Ариадненские базит-ультрабазиты продуцируют ряд крупных титаноносных россыпей. Так, судя по материалам Андросова Д.В. и Слободян Е.А. (2017 г.), протяженность россыпей р. Тодохова и ее правого притока руч. Потапова россыпей составляет соответственно 4.8 км и 1.2 км при ширине до 520 м и 280 м, средней мощности продуктивного пласта 7.4 м и содержанием ильменита до $375.5 \kappa \Gamma / \mathrm{M}^{3}$.

\section{Результаты исследований и их обсуждение}

Для решения поставленных задач потребовалось выполнить комплекс минералогических и технологических исследований. В пределах изученных россыпей было отобрано пять крупнообъемных проб (р. Падь Тодохова - 3, кл. Потапова - 2) весом до 500 кг, которые и послужили предметами исследований. В процессе технологических исследований исходные пески прошли стадию предварительного концентрационного обогащения с последующей электромагнитной сепарацией. Полученный гравитационный концентрат характеризуется высоким выходом магнитной фракции (93-95 \% общей массы) и низким - немагнитной (5-7 \%). Основу первой из них составляет ильменит, в небольших количествах фиксируется титаномагнетит. Отличительной чертой материала магнитной фракции является высокий уровень присутствия (до 800 г/т) таких высокотехнологичных металлов, как $\mathrm{V}, \mathrm{Nb}, \mathrm{Nd}, \mathrm{Co}, \mathrm{Cu}$. Немагнитная фракция, в сущности, представляет собой смесь анортита, кварца, роговой обманки, сфена и циркона. В незначительных количествах присутствуют монацит, рутил и апатит. Из рудных минералов преобладают сульфиды (единичные зерна пирита, арсенопирита, антимонита и галенита) и самородные металлы (золото, платина, цинк и никель). Составные компоненты фракции можно подразделить на две группы. Первая из них включает дефицитные для промышленности металлы Hf, Ce, Y (до 900 г/т). Во вторую входят Au и Pt, концентрации которых варьируют в пределах 0.5-3.0 г/т.

Особый интерес вызывают первые находки самородных платины и золота в россыпях узла. Для платиновых минералов характерно преобладание твердых растворов $\mathrm{Fe}-\mathrm{Pt}$, которые можно отнести, используя известную номенклатуру (Harris, Cabri, 1991) к изоферроплатине. Железистая платина обычно встречается в виде комковатых зерен неправильной или овальной, уплощенной формы, в поперечнике не превышающих 0.1 мм.

Все золотины, выделенные из немагнитной фракции, по особенностям химизма можно разделить на три группы: серебристую, ртутистую и медистую.

Серебристое золото. В первую, наиболее распространенную группу (до 70 \% всех изученных образцов) входят низко- и высокопробные, в понимании Н.В. Петровской (1973), разновидности золото-серебрянных соединений. Макроскопически низкопробные фазы - мелкие (менее 0.1 мм) пластинчатые, иногда комковидные частицы желтого цвета. Поверхность золотин - мелкоямчатая, окатанность - средняя, иногда хорошая. Они характеризуются сравнительно узким диапазоном колебаний пробы от 670 до 740 \%. На периферии зерен довольно часто наблюдаются гипергенные высокопробные оболочки толщиной 30-50 мкм, где концентрации Ag (1.6-1.8 мас. \%) значительно понижены по сравнению с центральной частью. Переход от матрицы к кайме резкий и хорошо прослеживается. Появление этих оболочек, по-видимому, связано с выносом примесей из золота в зоне гипергенеза. В отдельных зернах металла наблюдаются мелкие вростки арсенопирита. Химический состав этого минерала (Fe - 32.3, As - 42.6, S - 19.6 мас. \%) отличается избытком серы и дефицитом мышьяка по отношению к стехиометрии.

Другая разновидность золото-серебряных соединений характеризуется высокими значениями пробы (до 970-999 \%о). Спорадически в этих золотинах обнаруживается дискретные микроскопические обособления самородного серебра. Их появление, скорее всего, связано с гипергенными пре- 
образованиями низкопробного золота. Высвободившееся при этом серебро отлагалось в виде самостоятельной минеральной фазы.

Широкое развитие в рыхлых отложениях Ариадненского массива золото-серебряных фаз, возможно, является подтверждением участия в россыпеобразовании кварцево-жильных образований Тодоховского проявления золото-сурьмяной минерализации, генетически связанного с поздним гранитоидным магматизмом. Самородное золото подобных образований, по данным Э.М. Спиридонова и П.А. Плетнева (2002), наиболее серебристое в ряду плутоногенных гидротермальных месторождений.

Ртутистое золото. Представлено низкопробными ртутьсодержащими фазами (Au от 53.72 до 55.37 мас. \%, $\mathrm{Ag}$ от 39.1 до 41.45 мас. \%, $\mathrm{Hg}$ от 3.47 до 4.31 мас. \%). Они характеризуются невысокой гипергенной устойчивостью. Своеобразие вторичных преобразований выразилось в образовании высокопробной пористой диффузионной зоны шириной до 100 мкм, в которой практически полностью отсутствует Нg. Схожие изменения претерпевало гипогенное ртутистое золото в процессе формирования многих россыпей Урала (Мурзин и др., 1987). Отличительными чертами такого золота являются пониженные значения пробы, монолитное (плотное) внутреннее строение, прямая корреляция концентраций $\mathrm{Ag}$ и $\mathrm{Hg}$. Подобными характеристиками обладают изученные ртутистые фазы. Это позволяет сделать вывод о синхронной кристаллизации ртути и золота, а не о техногенном «заражении» шлихового золота в процессе эксплуатации россыпей. Таким образом, изложенные данные позволяют уверенно относить изученное ртутистое золото к природным твердым растворам системы Au-Ag-Hg.

Медистое золото. Эта группа состоит из тонких (менее 0.1 мм), относительно изометричных выделений золота ярко-желтого цвета с красноватым оттенком. Типоморфной примесью этих золотин средней пробы (850-900\%) можно считать $\mathrm{Cu}$ (0.1-3.2 ат. \%). В процессе микрозондовых исследований установлен неравномерный характер распределения этого элемента. Размер гомогенных участков редко превышает первые десятки микронов.

Ртутистый и медистый состав самородного золота россыпей, указывает на «ультрабазитовый» тип коренного источника. Так, находки самородного золота с высокими концентрациями Сu и Hg неоднократно отмечались в рудо-россыпепроявлениях, тяготеющих к базит-гипербазитам Урала (Сазонов и др., 2002), Приамурья (Молчанов и др., 2001). В пользу этой точки зрения, в нашем случае, свидетельствует близость макросоставов шлихового золота «ультрамафитового» профиля и его аналогов из ультраосновных пород. Факт сохранения геохимических характеристик россыпных золотин первично-магматического генезиса имеет принципиальное значение, поскольку может использоваться при металлогенических построениях, а также оценке перспектив ресурсного потенциала территорий не только юга Дальнего Востока но и других регионов.

В то же время, нельзя до конца исключать гипотетической возможности обогащения самородного золота за счет мафит-ультрамафитов, послужившими боковыми породами для флюидов, формировавших золото-сурьмяную минерализацию. Это взаимодействие могло сопровождаться выносом $\mathrm{Au}, \mathrm{Cu}, \mathrm{Hg}$ из ультраосновных пород, отличавшихся их повышенной концентрацией по сравнению с эдуктом, и с последующем поступлением этих элементов в гидротермальную систему.

Интерпретация полученных материалов приводит к выводу о том, что процесс формирования коренных источников россыпей Ариадненского узла охватывает длительный период времени. Его можно разделить на два этапа. На первом этапе, предположительно $\left(\mathrm{J}_{2}-\mathrm{K}_{1}\right)$, формировались собственно магматогенные ильменитовая и благороднометальная минерализации, связанные со становлением дифференцированного массива гипербазитов. Последующая магматическая активизация на втором этапе $\left(\mathrm{K}_{2}\right)$ привела к появлению золото-сурьмяных руд, ассоциирующих с поздними гранитоидными интрузиями. Разрушение вышеупомянутых магматических и рудных образований привело к поступлению в россыпи ильменита и минералов благородных металлов. 


\section{Заключение}

Результаты проведенных исследований дают основания полагать, что ариадненские базитультрабазиты активно участвовали в формировании россыпей, поставляя в них ильменит, медистое и ртутистое золото, минералы металлов платиновой группы. Находки золотин с включениями арсенопирита отражают факт участия в россыпеобразованиии других коренных источников. Выявленные индикаторные свойства шлихового золота позволяют не только уточнить особенности его генезиса, но и идентифицировать источники питания россыпей и локализовать участки их максимального распространения.

Применение современных технологий обогащения россыпей (Молчанов, 2008) позволит извлечь из них не только титан, золото, платину, но и весь спектр сопутствующих высокотехнологичных металлов (гафний, ниобий, иттрий, тантал, ванадий, неодим, кобальт и т.д.), с соблюдением ресурсосберегающих принципов и без нанесения существенного урона экологической обстановке. Представляется, что комплексное использование титаноносных руд и россыпей, связанных с базитультрабазитами, в значительной мере поможет удовлетворить потребности страны по целому ряду стратегических видов минерального сырья.

Работа выполнена при поддержке гранта РФФИ № 20-05-00525.

\section{Литература}

1. Анерт Э.Э. Богатство недр Дальнего Востока. Хабаровск. Изд-во: Книжное дело. 1928. 923 с.

2. Геодинамика, магматизм и металлогения Востока России (под ред. А.И. Ханчука). Кн. 1. Владивосток. Изд-во: Дальнаука. 2006. 572 с.

3. Молчанов В.П. Возможности ресурсосберегающей технологии извлечения полезных компонентов из техногенных и прибрежно-морских россыпей юга Дальнего Востока России // Экология и промышленность России. 2008. № 5. С. 41-45.

4. Молчанов В.П., Зимин С.С., Гвоздев В.И. Роль апогипербазитов в формировании платиноидно-золотых россыпей Гарьского узла (Среднее Приамурье) // Рудные месторождения континентальных окраин. Владивосток. Изд-во: Дальнаука. 2001. Вып. 2. Т. 2.С. 219-232.

5. Мурзин В.В., Малюгин А.А. Типоморфизм золота зоны гипергенеза (на примере Урала). Свердловск. Изд-во: УНЦ. 1987. 96 с.

6. Петровская Н.В. Самородное золото. М. Изд-во: Наука. 1973. 345 с

7. Сазонов В.Н., Мурзин В.В., Огородников В.Н. Золотое оруденение, сопряженное с альпинотипными ультрабазитами (на примере Урала) // Литосфера. 2002. № 4. С. 63-77.

8. Спиридонов Э.М., Плетнев П.А. Месторождение медистого золота Золотая гора (о «золотородингитовой» формации). М. Изд-во: Научный мир. 2002. 220 с.

9. Harris D.C., Cabri L.J. Nomenclature of platinum-group-elements allous. Review and revision // Can. Miner. 1991. V. 29. P. 231-237. 